\title{
Four books on capitalism
}

\author{
Wolfgang Streeck \\ Max Planck Institute for the Study of Societies, Cologne, Germany \\ Correspondence: ws@mpifg.de
}

Christoph Deutschmann Kapitalistische Dynamik: Eine gesellschaftstheoretische Perspektive. Wiesbaden, VS Verlag, 2008

Geoffrey Ingham Capitalism. Oxford, Polity, 2008

John McMurtry The Cancer Stage of Capitalism. London, Pluto, 1999

Frederic L. Pryor The Future of U.S. Capitalism. New York, Cambridge University

Press, 2002

Keywords: capitalism, crises, globalization, markets, financialization, financial institutions, state, government, social structure

JEL classification: P1 capitalist systems, G01 financial crises, G1 general financial markets

Suddenly it is capitalism all over again. The current crisis, more severe than anything since 1945, or for that matter since 1929, has once again made it respectable and sometimes even de rigueur to speak of capitalism instead of 'the economy'. What does the social science bookstore have to offer to those who have become newly curious, not just about the 'varieties' but about the nature of the beast? What did the authors of books written before the crash know, and what did they dare say, about capitalism's specific vulnerabilities, the risks it poses for the society that it inhabits and for itself, its periodic breakdowns and recurring fits of destructive insanity, and its seemingly unending need for reconstructive public intervention?

Frederic Pryor, the author of the most 'economic' of the four more or less randomly selected books reviewed here, is, according to Wikipedia, 'best known for his role in a Cold War spy swap'. In August 1961, as a student in West Berlin, 'Pryor was arrested and held without charge by the East German Police', to be freed six months later 'along with American U-2 pilot Francis Gary Powers' in exchange for 'Soviet KGB Colonel Vilyam Fisher (aka Rudolf Abel)'. Whatever 
this may mean, the book testifies that Pryor would deserve to be equally well known for his scholarly achievements - which, as his website indicates, are very impressive indeed. Clearly, Pryor's early Berlin experience has not affected his critical judgement, or made him feel obliged to project unshakable confidence in the economic system of the country that once bailed him out. Now a Professor Emeritus at Swarthmore, Pryor offers his readers a truly encyclopaedic review of the situation of American capitalism at the turn of the millennium, based on broad knowledge of the relevant literature inside and outside of economics, mainstream or not, surveying a wealth of data from a wide range of disciplines and ending with a well-reasoned, deeply sceptical view of his book's subject, 'The Future of U.S. Capitalism'.

Pryor's book is divided into three main parts, Internal Influences on the Economic System, External Influences and Changes in Crucial Economic Institutions and Organizations. In the first section, Pryor considers saving and economic growth (Chapter 2); economic fluctuations and financial crises (Chapter 3); economic inequality (Chapter 4) and globalization (Chapter 5). Next, in the section on external influences, he discusses natural resources and the environment (Chapter 6) and social (Chapter 7) and political factors (Chapter 8). In the third part, Pryor reviews the 'evolution' of business enterprises (Chapter 9), market competition (Chapter 10), government regulation and ownership (Chapter 11) and government spending (Chapter 12). Each chapter is replete with facts and figures, refers to a broad specialist and non-specialist literature, freely discusses alternative views and aims at empirically based, sound, common-sense judgements. The book is well-written in non-technical language and accessible also to readers outside the economics profession. Moreover, the author never fudges on his conclusions, which he freely exposes to debate.

As for method, Pryor casts a wide net, considering any factor that may somehow be relevant and trying to use any information available. One could speak of encyclopaedic empiricism or syncretistic eclecticism or both, with little a priori theoretical orientation. The result is a densely woven fabric of more or less well-established causal relations and interactions between innumerable variables - an honest and down-to-the-facts reconstruction of causes and effects as found in the real world, which unfortunately sometimes becomes as confusing as the latter.

Of special interest to social scientists may be what an economist like Pryor has to say on the social and political factors he considers likely to influence the future of capitalism in the USA (Chapters 7 and 8, pp. $175 \mathrm{ff}$.). Among social trends, Pryor emphasizes 'the breakup of the traditional family', 'the decline of social capital' as described by Inglehart and Putnam and 'declining social trust and deepening social cleavages' (for an interesting list of indicators for the latter, see 
p. 180). Pryor considers that such trends may not continue, but he has no theory to determine what is more likely, further decay or recovery. In any case, assuming that social disintegration will not stop, Pryor runs various quantitative crossnational comparisons that, as he interprets their results, speak against disintegration having direct economic effects either way (p. 191). The same seems to be true for cultural and value changes as reported early by Daniel Bell and later by the post-materialists. In fact, Pryor identifies three 'non-trends' that have failed to materialize: a rejection of consumerism, 'a crumbling of the entrepreneurial spirit, and a loss of individualism' (p. 198). According to Pryor, neither saving nor the 'work ethic' nor entrepreneurialism is on the decline in the USA, and Americans remain 'resolutely acquisitive, individualistic, and hard-working' (p. 206). However, and at the same time, as pointed out in the subsequent chapter on 'political factors', ongoing cultural shifts do affect importantly and adversely 'the future effectiveness of economic institutions and organizations':

The decline of social capital and trust will raise transactions costs and expenditures for domestic security, and, moreover, will increase difficulties in reaching a political consensus necessary for effective governmental economic policies. The attitudes toward government, combined with its declining effectiveness, will strengthen those forces pushing our political system toward an economic-political oligarchy. (p. 236)

While far from being your usual radical, in his final chapter (pp. 352 ff.) Pryor offers in summary a formidable array of dire predictions based on the analyses in the body of his book. In a matter-of-fact way, he presages 'a stormy economic atmosphere' for US capitalism, in particular 'declining economic growth', 'increasing volatility', 'widening income differentials' and 'unsteadily rising globalization'-by which he means that

the globalization process leads to diminished ability of national governments to regulate business within their own borders and to protect particular segments of the economy that are considered politically important to protect... . Thus, globalization acts in important respects to reduce the political impact of voters and this, in turn, might lead to a serious nationalist backlash .... (p. 354)

Pryor also expects a decline in economic competition (pp. 355 f.) due to continuing mergers and the rise of giant international firms, as well as international cartelization. As for the role of government, he sees continuing deregulation at the national level 'reinforced by the growing inequality of income, since the business elite will have more economic power to block and/or weaken unwelcomed restraints placed on their activities' (p. 359). Countervailing tendencies include the possibility of stricter financial regulation 'to reduce shocks to the 
economy that arise from this sector' (p. 359); pressures for government to compensate lower private savings through public investment; and increased environmental regulation. Pryor expects public expenditure to rise, especially because 'ever greater income inequality' will require more spending on internal security and on social policy, 'on the assumption that beyond a certain point, increasing inequality in the area of health becomes politically unsustainable' (p. 359). At the same time, as indicated, in a more divided society and more open economy, the efficacy of government he considers likely to decline, and this is said to be also true for the confidence of the population in political participation:

Under circumstances that might possibly arise in future decades, greater political apathy on the part of ordinary citizens, combined with their increasing alienation reflecting the decline in social capital, could lead either to a rise in governmental despotism and/or the fusion of political and economic elites into a more oligarchic regime. (p. 361)

Finally, Pryor expects social capital and social trust to continue to deteriorate, due to growing social heterogeneity, the spell held by the entertainment industry over normal people, and globalization. The consequences are 'a fall in political participation and trust in government' (p. 362). The current decline of crime rates may or may not continue, but then 'the nature of crime appears to have shifted - from visible assaults, robberies, and murders to less detectable whitecollar crimes, so that our indicators of crime have become ever more faulty' (p. 362). Deteriorating social capital and trust, in addition to increasingly impaired governability, are also likely to diminish 'entrepreneurship, technological cooperation between companies, and the degree to which managers take their responsibilities seriously' (p. 363). They also generally raise transactions costs. Pryor summarizes his vision of the future as follows:

From the evidence presented in this book, I do not see sunny skies for the future of U.S. capitalism .... Along the political dimension, the overall level of government intervention will be roughly the same, but with a different composition: public expenditures will be higher, regulation of industry will be lower, government intervention in the economy will be less effective, and repression of the population will be harsher. Along the economic dimension, markets will be less competitive. And along the social dimension, solidarity will probably be less, and, despite increased affluence, the quality of our lives will deteriorate and economic life will be more pitiless. (p. 364)

Writing three years before Pryor, John McMurtry, a moral philosopher and ethicist at the University of Guelph in Ontario and, as one finds on the Internet without much effort, a leader in the anti-globalization movement, offers a conceptually and 
theoretically much tighter account, both bleaker and more hopeful than Pryor's, of what he considers 'the cancer stage of capitalism'. McMurtry's oncological metaphor carries him surprisingly far, and at times the book is absolutely fascinating reading to professional social scientists conditioned by their disciplines to weigh their words carefully_perhaps excessively carefully. The book lives off its analogy between social and cellular organisms, or 'life organizations'. Both are considered vulnerable to disease in the form of destructive pathological growth. Also, each is defended by an 'immune system', one organic, the other social-political, that may be disabled by malignant invaders that they fail to recognize as such. Cancerous growth in capitalism, in other words, threatens public health in a major sense and ultimately brings death to the social body unless it is identified, fought and defeated by its 'forces of life'. The image this projects is obviously reminiscent of Karl Polanyi's notion of a struggle between market expansion, on the one hand, and social 'countermovements' aiming to protect society from being torn apart by its market economy, on the other.

McMurtry's key experience seems to be the political economy of the 1980s and 1990s in North America, especially the USA, in particular the era of simultaneous financialization and globalization of modern capitalism. This was a time when it became common for normal people everywhere to be given the bizarre message that they had to make 'sacrifices' in their standard of living so as to remain 'competitive' in the 'global marketplace' and to defend their standard of living, and that they had no choice but to accept a lower standard of living if they desired to continue to have choices and remain prosperous. Several times, McMurtry reminds us of the Reagan years, when interest rates were raised to wipe out entire industrial sectors and their labour unions; arms spending was absurdly increased; resistance movements in South America and elsewhere were massacred; taxes on the rich were slashed; and the resulting public deficits served as an excuse for cutting social spending and privatizing public services. Anyone who is interested in an intellectually respectable attempt at synthesizing and giving coherent meaning to these and other events, and in a defence of antiglobalism that is probably as good as it can get, should look at this book-not least because of its impressive potential to contribute to a better understanding of the sources and probable consequences of the worldwide financial crisis that began a decade after the book was first published.

Indeed, it is in this respect that McMurtry's cancer metaphor seems to work best (pp. 115 ff.). McMurtry's analysis starts with Marx's famous equation, $\mathrm{C} \rightarrow \mathrm{M} \rightarrow \mathrm{C}$, which, of course, symbolizes the extended exchange of use values mediated by money, and $\mathrm{M} \rightarrow \mathrm{C} \rightarrow \mathrm{M}^{1}$, which denotes the process of capital accumulation where use values become subservient to increasing the money capital originally invested in them. Unlike classical Marxism, and with the experience of the post-war era of 'embedded liberalism' behind him, 
McMurtry has, by and large, made his peace with the notion that in contemporary society, the producers of use values work not primarily to serve the needs of humankind but to turn their money into more money. Society, McMurtry suggests, has learnt to live with this and benefit from it, mostly through the institutionalization of social rights of citizenship, the welfare state, free trade unions and market regulations of all sorts. Where capitalist growth gets cancerous, however, is where the making of money-or the growth of the capitalist economy-becomes detached from the making of use values, i.e. where the formula of extended reproduction is re-written to read $\mathrm{M} \rightarrow \mathrm{M}^{1} \rightarrow \mathrm{M}^{2} \rightarrow \mathrm{M}^{3}$ $\rightarrow \mathrm{M}^{n}$, or

$$
\$ \rightarrow \$^{1} \rightarrow \$^{n}
$$

It is not capitalism as such, McMurtry suggests, that is destructive, at least not since the body social has over time acquired the capacity to control it and make good use of it. What makes capitalism pathological, or has made it so again, is a development that began with the breakdown of the Bretton Woods world economic order. In its course, money ceased to be what it also had been, in addition to capital: a public institution directing economic activities into productive endeavours. Instead, it was reduced to being a commercial commodity itself, decoupled from its previous functions for the real economy and the circulation of use values in it, ${ }^{1}$ in the process becoming capable of growing like weeds, or cancer for that matter, through the magic of securitization and compound interest. 'Globalization' was central to what came to be called 'financialization' as it allowed for a 'free flow' of capital in unlimited world markets:

Because there never was an internal limit to traditional capital which would inhibit this pathogenic sequence of growth $\left[\$ \rightarrow \$^{1} \rightarrow \$^{n}\right.$; WS], we might say that the potential of carcinogenic mutation and invasion of social hosts has existed from the beginning. For centuries, however, a horizonless stretch of cultures, habitats and natural elements, national boundaries and regulations of trade, society-wide movements to protect working people's capacities and their local environments, a global spread of liberation movements against colonization and expropriation of resources, the growth of public sectors and welfare systems out of world depression and war crises over the last century, and the institutionalization of alternative forms of socialist organization together hedged in the uncontrolled growth of money sequences. (pp. 127 f.)

\footnotetext{
${ }^{1}$ 'The defining principle of this investment mutation is that it is no longer bounded by any national base or interest or regulation, or by any other direct or indirect requirement to commit itself to any productive function beyond itself (p. 117).
} 
Like cancer in the body, financialization at first failed to elicit an immune response in the social system, probably because it managed to camouflage itself as capitalist 'business as usual'. In this it was aided by the dismal state of standard economics as an intellectual enterprise, which propagated a mechanistic image of the social world representing it as a machine (see Chapter 4, pp. $132 \mathrm{ff}$., with an intriguing discussion of the difference between what McMurtry calls the 'Life Code' and the 'Money Code', respectively ${ }^{2}$ ). Thus, cancerous growth could be confused with healthy, normal growth-not really surprisingly since already under oldfashioned, traditional capitalism, only market transactions that had a price expressed in money units were counted as contributing to the 'wealth of nations'. The new 'money sequences', according to McMurtry, driven by the 'financial industry' having acquired the capacity and the license to make money out of money, generate claims to resources at a rate so rapid that the real economy cannot possibly follow. Thus, more and more people, living today or in the future, must in any of a multitude of ways be made to indebt themselves with the current owners of artificially created money, mortgaging to them the proceeds of their future labour and thereby promising to redeem rapidly increasing entitlements to not-yet-existing goods and services. Ever-increasing 'money-demand' - in the sense of claims of current holders of money on future goods and labour - manufactured by a financial system running wild can, however, be served only by subjecting ever more spheres of life to the logic of marketization. Commercializing ever more as-yet noncommercial transactions and social relations, so they can turn a monetary profit, requires the privatization on a grand scale of what McMurtry refers to as the global and social commons. Capitalism in its cancer stage thus subjects the lifeworld to 'the mutating money sequence of value' or, in the language of McMurtry's intriguing metaphor,

to a sequence of uncontrolled multiplication of an agent which overruns the host body with demands for growth which have no committed function to the life-host, and whose decoupled appropriation of its nutriments deprives the life-host of what it requires to sustain its vital functions. (p. 132)

Among the symptoms of the 'carcinogenic invasion' of the body social by a financial system operating out of public control are the appropriation by private business of 'public sectors of revenue'-revenue to 'life', not to money

\footnotetext{
${ }^{2}$ On standard economics, see Chapter 1 in particular, where instructive examples are given of the rise and persistence of intellectual orthodoxies and taboos: 'Socrates..., despite his reputation as an inveterate interrogator of conventional opinion, never went so far as to seriously query his society's belief in enslaving other people to do its work, nor did he ever think to question the system of aggressive war and imperialism upon which this enslavement was based' (p. 2)—although he clearly had all the tools required for this in his philosophical apparatus.
} 
owners; the expanding 'debt and deficit circuits' that disassemble and marketize communal infrastructures around the world (another, and ongoing, primitive accumulation); the rise of a powerful 'constituency for instability' that stands to benefit from speculative price changes that mean life-threatening uncertainty for most people; and large-scale environmental deterioration. Unlike biological immune systems, however, social ones, according to McMurtry, can learn from experience, and this is why the book does not at all end in despair. (For a political activist like McMurtry, anything else would, of course, be surprising.) In his final chapter, 'The Great Vehicle of the Civil Commons' (pp. 190 ff.), McMurtry develops his vision of a collective global defence of social rights to basic life-sustaining goods and services. By 'civil commons', he means the entirety of collectively owned and consumed, exclusively collectively sustainable and properly priceless 'necessities of life' (Adam Smith), from a common language and morality to unemployment insurance and the grasslands of Mongolia, including the ancient village commons before enclosures' (pp. $206 \mathrm{f}$.), which are all threatened or were historically destroyed by commodification and monetarization.

The civil commons, McMurtry argues, while it is today more than ever under attack by cancerous economic growth, can never be completely demolished as long as there is life on earth. In fact, the sense of community it inevitably sustains provides the basis for its political defence-as seen in the French protests in the 1990s against neo-liberal reform and 'globalization', or in the demonstrations of peace movements around the world, such as those in the 1960s against the war in Vietnam. Protecting and restoring the civil commons today will above all require a vigorous political immune reaction against the nodes of the cancer, the 'banks and financial institutions'. As these nodes are 'ultimately the privileged creatures of government's discretionary entitlements', there is no reason in principle why they should not again be brought under public control:

In a pure-type situation, all money-creating powers revert to public authority, are tied to the rate of real economic growth so as to avoid inflation, and are lent to enterprises producing goods serving the life economy. (247 f.)

McMurtry concludes by observing (p. 254):

The unseen master-switch of [the] subversion of the public sector's lifeprotective function is the covert acquisition by private financial institutions of control over the most basic financial instruments and powers of public authority. The instituted resources for the reversal of this covert usurpation have already been won by a millennium of democratic development. The choice paths for social recovery are clear and available. The missing link remains social recognition of the systemic nature of the underlying disorder and the logic of its dissolution. 
Compared with McMurtry, Geoffrey Ingham's book, entitled simply 'Capitalism', is much more accessible, and certainly written with more professional discipline and style. But there are also interesting and indeed exciting parallels, to which I will proceed shortly. The book appeared in the Polity Press series 'Key Concepts', which explains its laconic title and somehow defines it as a general introduction for the uninitiated. In fact, however, it is much more: not just an excellent summary of key themes and the literature on capitalism, but also a highly instructive first approach to the contemporary issue of all issues, the global financial crisis. (The book appeared in 2008 and the last touches to the manuscript seem to have been made in the summer of that year when the crisis was beginning to unfold.)

'Capitalism' is organized in two parts, the first presenting 'classical theories' on the subject and the second reviewing capitalism's 'institutions'. Among theories, we are treated to the usual suspects: Smith, Marx, Weber, Schumpeter and Keynes. While Ingham tries to distribute his favours evenly, his sympathies clearly lie with a combination of Schumpeter and Marx, closely followed by Keynes. On the basis of his reading of the classics, Ingham suggests that a capitalist economy consists of three 'fundamental elements, or institutional clusters' (p. 53): 'a monetary system for producing bank-credit money; market exchange; and private enterprise production of commodities' (ibid.). He emphasizes that the three do not stand alone and by themselves, but rather interact with and depend on two crucial supports, the state and a modern, capitalist culture. Part II, then, reviews what Ingham considers the five core institutions of capitalism, money (Chapter 4), market exchange (Chapter 5), the enterprise (Chapter 6), capital and financial markets (Chapter 7) and the state (Chapter 8). The book ends with 20 or so pages of concise and highly readable conclusions.

The chapters this reviewer liked most are those on 'Money' and 'Capital Markets' (although the others are to be highly recommended as well). This is not surprising, not just because of the current political-economic circumstances but also since Ingham, a sociologist at Christ's College, Cambridge, has in the past established himself as an authority on the subject, among other things with his book The Nature of Money (2004). Most sociologists, or socio-economists, working on political economy concern themselves with labour or culture, and a few with the environment, usually in relation to politics and the state, while leaving the intricacies of money and the financial system to the specialists. More often than not, however, these researchers have a stake in hiding their knowledge, if that is what it is, in unintelligible jargon so as to keep it to themselves, or they go native altogether in the strange but bountiful lands that they once set out to explore. As it now turns out, leaving money to the money-makers in the banks and their associated university departments of finance was a big mistake, and we must be grateful to scholars like Ingham for having made the considerable investment required in order to enter this difficult field armed with the necessary expertise. 
Finance, as we have seen, is also central to the anti-globalization diatribe of McMurtry, written almost a decade before Ingham's introductory text. As indicated, this reviewer finds it remarkable that the two are not all that far apart in diagnosing the origin of a crisis that unfolded only when their books were already out. To both, notwithstanding the technicalities with which 'finance theory' tries to scare away innocent citizens, the core of the matter is a newly developed capacity of a newly global financial system to make money out of money, avoiding the old-fashioned and tiresome detour through the production of useful goods and services $\left(\mathrm{M} \rightarrow \mathrm{M}^{1}\right.$; Ingham, p. 50). Ingham, in particular, explains how the politics of deregulation and internationalization, together with computer-based finance mathematics, finally extricated the capacity to produce money by credit from public control—which to some extent at least had tied it to the production and consumption capacities of the real economy.

Central to Ingham's argument is his observation that it was always a 'defining characteristic of capitalism that private debt can be readily transformed into money' (p. 66), a capacity that continues to be capitalism's 'dynamic engine of growth'. Money, in other words, is fundamentally 'constituted by a social relation of credit-debit' (p. 69), i.e. by private promises that private debt will eventually be repaid. This implies that modern capitalist money 'can only be made scarce by the rules and norms that govern the contracting of debt by the state and the private sector' (p. 75). Globalization and deregulation, as McMurtry also notes, have eroded those rules and norms and thereby made possible privatized money production on a hitherto unknown scale. In the narratives of both Ingham and McMurtry, this represented a response to the general stagnation of growth and profitability that became a problem for Western capitalism after the end of post-war reconstruction and with the rise and consolidation of the socialdemocratic welfare state in the 1970s.

Fresh money engineered to enrich the rich $^{3}$ had to find debtors willing to take it, in return promising to repay it in the future with interest. The inevitable result was a rapidly growing debt pyramid vastly in excess of the real economy's ability to pay, one that became increasingly liable to collapse as it was losing its

\footnotetext{
${ }^{3}$ Ingham reports that the making and selling of money always carried the highest monetary rewards of all branches of the capitalist economy. In recent years, however, the tributes extracted by the capi of the financial sector reached obscene dimensions, at a time when the dominant economic theory in Western societies prescribed lower wages for the masses as the only means to restore dynamism and competitiveness. Ingham mentions Goldman Sachs' earnings in 2006, which amounted to $\$ 9.5$ billion, 'providing for an average annual salary (excluding bonuses) of $\$ 620,000$ for the staff of 26,000 , and over $\$ 50$ million for [the CEO] himself' (p. 158). He also cites a report in the Financial Times according to which in the same year 'the combined earnings of the world's top 25 hedge fund managers of almost $\$ 15 \mathrm{bn}$ exceeded the national income of Jordan', with three individuals 'taking home more than 1bn' (p. 173f.).
} 
grounding in the much more limited world of marketable use values. Ingham refers to Minsky's theory, today so popular, that capitalist development is permanently at risk of being ended by either the Scylla of price inflation or the Charybdis of debt deflation. In 2009, it was the latter that forcefully emerged. Taking into account the fact that money is essentially a public good, even in a capitalist economy with private banking, national states had no choice, short of fundamental reform, but to deploy their authority in order to restore economic confidence. The way this was done was by procuring new credit from future generations unable to object to being drafted for bailing out today's merchants of debt and dealers in what ultimately could not but turn out to be empty promises.

The fourth and final book to be reviewed here, Christoph Deutschmann's Kapitalistische Dynamik, is available only in German. This is unfortunate since it clearly deserves to be more widely accessible. The book is a wide-ranging collection of essays written separately for different occasions. Still, it is remarkably coherent. Capitalist Dynamics: A Social-Theoretical Perspective begins with a highly original, indeed daring exploration of what Deutschmann calls 'the elective affinity (Wahlverwandtschaft) between capitalism and religion', based less on Weber and Marx than on Walter Benjamin and Emile Durkheim, and in particular on Georg Simmel and his theory of money as the all-encompassing and allpowerful integrative force in modern societies. With considerable erudition, and not without a subtle melancholic sense of irony, Deutschmann elaborates on the structural parallels between monotheism and the money economy, pointing out against Weber the essentially irrational, or rather non-rational, foundations of the capitalist mode of production and way of life. Capitalist development, according to Deutschmann, requires and produces above all uncertainty and unpredictability. Its progress depends on creative action as well as creative destruction, and it requires collective faith in a utopian-religious promise of unlimited freedom and prosperity, as embodied in the essentially unlimited potential of Simmel's 'absolute means', money. ${ }^{4}$

Much like Ingham, Deutschmann's theory of capitalism represents an interesting synthesis of Marx and Schumpeter, which apparently is the way to go today. Also like Ingham, and in line with McMurtry, special attention is given to the centrality of money, where Deutschmann forcefully brings in Keynes in addition to Simmel. Clearly, there is no lack of ambition in a book that deals not just with entrepreneurship but also with the labour process; with the changing nature of labour markets as well as financial markets and markets for consumer goods; and with the dynamics

\footnotetext{
${ }^{4}$ Writing in German, Deutschmann benefits from the double meaning of the word Vermögen, which may be translated as both 'capacity' and 'fortune'. Readers of German will find an advanced version of Deutschmann's reception of Simmel and Durkheim at http://www.mpi-fg-koeln.mpg.de/pu/ workpap/wp09-5.pdf.
} 
of consumption as well as of technological innovation; not to mention several other big subjects. For example, readers find an intriguing and, as far as this reviewer knows, unique Schumpeterian critique-cum-rehabilitation of Marx's labour theory of value, together with an enlightening social-structural account of the current financial crisis written, again, before the event. While in many ways similar to what we find in McMurtry and Ingham, Deutschmann's version entails a further twist to which I will turn shortly. All in all, what the book appears to aim at is nothing less than a sociological-evolutionary theory of capitalist development and capitalist growth, and in particular of their social limits - a theory which resolutely abandons Weber's rationalist articles of faith, suggesting instead an action-theoretical account of institutional change based on pragmatist premises that brings together micro- and macro-level sociological analysis in a novel and, at least for this reviewer, highly productive manner.

The four chapters that follow Deutschmann's discussion of the relationship between capitalism and religion deal with the dynamics of economic institutions. At their centre is the idea that the creativity of Schumpeter's entrepreneur is in fact a property not just of individual capitalists, but of labour power in general, including waged labour. Marx's fundamental intuition that it is only labour, and not capital, be it machines or money, that can create more value than it consumes is resurrected to become the core of a theory of the social-institutional dynamism of capitalism. The mythical promise of unlimited possibilities inherent in the institution of money is argued to have become the driving force behind a comprehensive mobilization and actualization of the equally unlimited potential of human labour to build and rebuild the world, and indeed humanity itself. Money simultaneously unbinds and binds the fundamental creativity of human action and societal labour. This idea is further developed in the third part of the book, where Deutschmann returns to his earlier work as a sociologist of work and industry. Here he argues, among other things, that a purely market-driven, neo-liberal organization of the labour process, one that refuses workers the opportunity to identify with professional skills and status, will deprive capitalist development of access to the 'autonomous competence and creativity' (p. 129) of workers-resources on which it vitally depends although it seems to be unable over the long run to safeguard and activate them.

In fact, a central concept in Deutschmann's theory of the dynamics of capitalism is that of contradiction. Conditions and processes that are shown to be indispensible for capitalist progress are also shown to be ultimately impossible to sustain, or likely to give rise to latent and unintended effects which subvert them. This is particularly in evidence in the final section, entitled 'Global Financial Markets, Corporate Governance and the Middle Classes' (pp. 151 ff.). Like McMurtry and Ingham, Deutschmann sees 'financialization' as a process in 
which excess money chases increasingly scarce opportunities for profitable investment in the 'real economy'. But while the cause of the mismatch is usually seen in financial 'innovation' devised to turn money directly into more money, Deutschmann adds the changing social structure of advanced capitalist societies as a further and, in his view, probably more important, ultimate cause. Moreover, where others tend to look only at the peak of the stratification pyramid, the very rich, Deutschmann's analysis considers the entire social spectrum, including, in particular, the middle classes.

Fifty years of peace, so Deutschmann's central argument, have allowed private assets in the rich countries of the West to grow to a historically unprecedented level, turning the rentier of the inter-war period into a true mass character. Deutschmann identifies the rentier's desire, and perhaps need, to invest his money profitably - to let others work with it on his behalf-as one of the driving forces of financialization. Where Keynes went wrong, according to Deutschmann, was in believing it to be possible that capitalist societies would one day, swamped with accumulated surplus capital, be able to pursue economic policies aimed at the 'euthanasia of the rentier'. Deutschmann views the post-1970s as a period in which money owners clipping coupons of all kinds made a powerful comeback politically and economically from their decade-long impotence under the post-war settlement, increasingly supported by a growing constituency of would-be beneficiaries of 'institutional investors' of all sorts, including a growing class of middle-class savers. To them, 'globalization' created a host of new opportunities to make capital, which was in principle in abundant supply, artificially scarce, and to dictate new and ever more stringent conditions to governments, citizens and workers in the rich countries as well as the poor ones. Far from being put out of business, the newly organized and re-empowered rentiers successfully demanded deep changes in economic policy and industrial organization, as well as in labour markets, corporate governance and the public provision of services and social protection, all aimed at expanding available opportunities for the profitable investment of ever more sophisticated forms of private capital.

Investment, of course, means giving money as credit to debtors who promise to repay it at an agreed rate of interest within an agreed period of time. The profitable investment of capital, therefore, presupposes that there are enough entrepreneurs in the broadest sense that are willing to indebt themselves and then work hard to pay off their debt, thereby securing a steady stream of effortless income for their creditors. This, in turn, requires a widespread desire to move up in the social world through individual achievement, and a general climate of optimism. Deutschmann argues that these conditions are unlikely to exist in societies, like most European ones today, where the broad middle classes are basically satisfied with the prospect of high returns on their savings, whether self- 
made or inherited. Especially where populations are ageing, past economic achievement reduces the number of possible debtors, leaving would-be creditors at the mercy of 'finance industry' artists who promise them ever higher returns. Inevitably, speculative bubbles ensue. Moreover, while a possible solution might be capital export to parts of the world where people are still willing to take risks in the real economy and exert themselves to overcome them, this creates problems of its own, both internationally and nationally. These include growing inequality in the rich countries, where the poor are deprived of the jobs and the incomes they would have access to if domestic capital continued to be invested domestically rather than in international markets; the traumatic disruption of traditionalist ways of life in the countries where capitalist relations of production need to be newly introduced; and unpredictable disturbances in international trade and finance. 